\title{
Anonna muricata Linn Leaf Effect in Inhibiting SGPT Elevation
}

\author{
Galih Tanaya ${ }^{1}$, Kuswinarti ${ }^{2}$, R Nina Susana Dewi ${ }^{3}$ \\ ${ }^{1}$ Faculty of Medicine, Universitas Padjadjaran, ${ }^{2}$ Department of Pharmacology and Therapy, \\ Faculty of Medicine, Universitas Padjadjaran, ${ }^{3}$ Department of Pathology Clinic, Faculty of \\ Medicine, Universitas Padjadjaran/Dr. Hasan Sadikin General Hospital, Bandung
}

\begin{abstract}
Background : Hepatitis is an infection or inflammation disease of the liver which is caused by virus, toxic substance, and immunological abnormalities. Soursop plant as a medicinal plants is known to have an antioxidant effect and nowadays is used as an alternative drug for hepatitis. One of the methods to assess liver function is to measure the serum Glutamate Piruvate Transaminase (SGPT) level. The purpose of this study was to find the effect of Soursop Leaf in inhibiting the SGPT elevation .

Methods: An experimental study was conducted on 25 white male rats of wistar strain in the pharmacology laboratory of Faculty of Medicine, Universitas Padjadjaran during the period of September to October 2012. The rats were divided into 5 groups (group 1 and 2 as control; group 3, 4, and 5 as treatment groups treated by $200,400,600 \mathrm{mg} / \mathrm{kgbw}$ soursop extract, respectively). The soursop extract was administered to the treatment groups for 8 days. On the 8th day, group 2, 3, 4, and 5 received $1.6 \mathrm{ml} \mathrm{CCl} 410 \%$ intraperitoneally. After 18 hours, the mean SGPT levels from all groups were measured. ANOVA test was used to analyze the result.

Results : The mean SGPT levels were lower in the 3rd, 4th, and 5th group compared to group 2. There was a significant difference among treatment groups. Group 3 had the most significant result.

Conclusion: Soursop leaf inhibits the elevation of SGPT level.
\end{abstract}

Keywords: Hepatitis, SGPT, soursop leaf (Annona muricata)

\section{Introduction}

Liver is the largest gland in the body, the weight average is 1500 gram in adults. Liver has a main function as a filter for blood. ${ }^{1}$ The blood circulating the body will be cleansed and filtered from toxins that enter the body through food or respiration..$^{1,2,3}$ Other hepatic functions are storing many forms of glucose, vit B12, and iron, energy provider (sugar) and protein, hormone secretion, insulin secretion, lipid and cholesterol forming and excretion. ${ }^{1,2}$ Liver also functions in detoxification as a filter and excretor of toxins in blood through hemoglobin dismantling, and processing ammonia into urea. ${ }^{2}$ One of the methods to assess liver function is to measure the serum level of glutamate piruvate transaminase (SGPT). Hepatitis is an infection or inflammation disease of the liver which is caused by virus, toxic substance, and immunological abnormalities. ${ }^{4}$
Indonesia has many traditional medicines and medicinal plants. Medicinal plants as herbal medicine is developing, aside from being relatively affordable, herbal raw materials are also easy to obtain and grow in the environment, and do not has any adverse effects known to man. ${ }^{5}$ Herbal medicines are known to work as anti-oxidant, antiinflammatory, analgesic, etc. ${ }^{6}$ This is related to the fitochemical substances contained in medicinal plants . $^{3,7-9}$

Anti-oxidant is substance which functions to protect the body from free radicals. Some examples of anti-oxidant are vitamins, poliphenol, karotin, and minerals. Naturally, these substances have a significant role to prevent diseases. Anti-oxidant prevents diseases by suprressing the damage on cells due to oxidation of free radicals. ${ }^{3,7,8}$ Free radicals have unpaired electrons which are not stable and will try to find electron pairings. Environmental activities that can produce free

Correspondence: Galih Tanaya, Faculty of Medicine, Universitas Padjadjaran, Jalan Raya Bandung-Sumedang Km.21, Jatinangor, Sumedang, Indonesia, Phone: +62 8157146851 Email: tanaya701gt@gmail.com 
radicals are as follows: radiation, pollution, etc. Free radicals which circulate the body will try to find electron pairings with other molecules such as Deoxyribo Nucleatid Acid (DNA) and cells. If electron pairing is succesful, it will disrupt the cells and DNA. ${ }^{10}$ Anti-oxidant helps to inhibit this process by donating an electron to free radicals. Anti-oxidants will neutralize the free radicals as such that they do not try to find electron from cells and DNA., 3,8

One of the substances that can produce free radicals is Carbon Tetrachloride $\left(\mathrm{CCl}_{4}\right)$. The liver produces $\mathrm{CCl}_{4}$ into the free radical $\mathrm{CCl}_{3}$ which then oxidizes the unsaturated fatty acid in phospholipid layers of cellular or organel membranes, so then damages hepatic cells and can induce necrosis. The $\mathrm{CCl}_{4}$ is regarded as a hepatotoxin. ${ }^{11}$

Liver cell damage can be inhibited by many hepatoprotector substances which are chemicals that can protect the liver cells. ${ }^{12}$ One of the easily obtained anti-oxidants is from soursop leaf. ${ }^{12}$ Soursop plant is one of the vegetations functioning for health. ${ }^{8}$ In each region in Indonesia, soursop plants have many different uses for diseases and are known used as an alternative drug for hepatitis and other diseases such as asthma, bronchitis, diabetes mellitus, etc. ${ }^{5,8,13}$ Soursop have many useful substances such as the flavonoids and ascorbic acid in the leaves which are known to have anti-oxidant properties. ${ }^{3,6,7}$ According to the background stated above, this study aims to know the effect of soursop leaf extract (Annona muricata) on hepatitis model rats which are induced by $\mathrm{CCl}_{4} \cdot{ }^{9,10,14,15}$

\section{Methods}

An experimental study conducted on 25 white male rats of wistar strain which were healthy, aged 2-3 months old with weight between
200-300 grams. This study was carried out in Pharmacology Laboratory of Faculty of Medicine Universitas Padjadjaran during the period from September to October 2012.

Preparation of Soursop Leaf Ethanol Extract (SLEE) was conducted through several steps as follows: 1) Fresh soursop leaves were washed and dried by exposure to direct sunlight or indirectly through a black fabric, 2) The leaves were grinded and extracted using ethanol 70\%(maseration method), 3) The extract liquid was evaporized until a viscous extract was obtained.

The rats were divided into 5 groups (group 1 and 2 as control groups, group 3, 4, and 5 as treatment groups, were given each 200, 400, $600 \mathrm{mg} / \mathrm{kgbw}$ soursop extract). Soursop extract was then administered to the treatment groups for 8 days.

On the 8th day, group 2, 3, 4, and 5 were administrated $1.6 \mathrm{ml} \quad \mathrm{CCl}_{4} 10 \%$ intraperitoneally. The damage caused by $\mathrm{CCl}_{4}$ which is a hepatitis causing free radical is by increasing calcium influx from the swelling of smooth and rough endoplasmic reticulum. Due to this calcium influx, the SGPT in cytosol rose in rats belong to groups II - V which were induced with hepatitis by injection of $\mathrm{CCl} 4$ $10 \% 1.6 \mathrm{~mL}$ per intra peritoneal (IP) in the abdomen.

After 18 hours, mean SGPT levels from all groups ware measured. A Shapiro test ( $p \geq$ 0.05 ) was carried out and the data results were not normally distributed. In the relation in that results, data transformation was carried out. ANOVA test was used to analyze the result.

\section{Results}

After each treatment with soursop leaf extract, the mean SGPT level is lower in the $3 \mathrm{rd}$, 4th, and 5th group compared to group

Table 1 SGPT Level of each Treatment after Administration of Soursop Leaf Extract

\begin{tabular}{cccc}
\hline Group & $\mathbf{n}$ & $\begin{array}{c}\text { Mean Level SGPT } \\
(\mathbf{x} \text { 10 }\end{array}$ & \\
& & & IU $/ \mathbf{L})$ \\
Group 1 & 5 & 0.060 & 0.017 \\
Group 2 & 5 & 18.246 & 1.174 \\
Group 3 & 5 & 7.636 & 0.634 \\
Group 4 & 5 & 11.334 & 1.871 \\
Group 5 & 5 & 13.950 & 1.029 \\
\hline
\end{tabular}




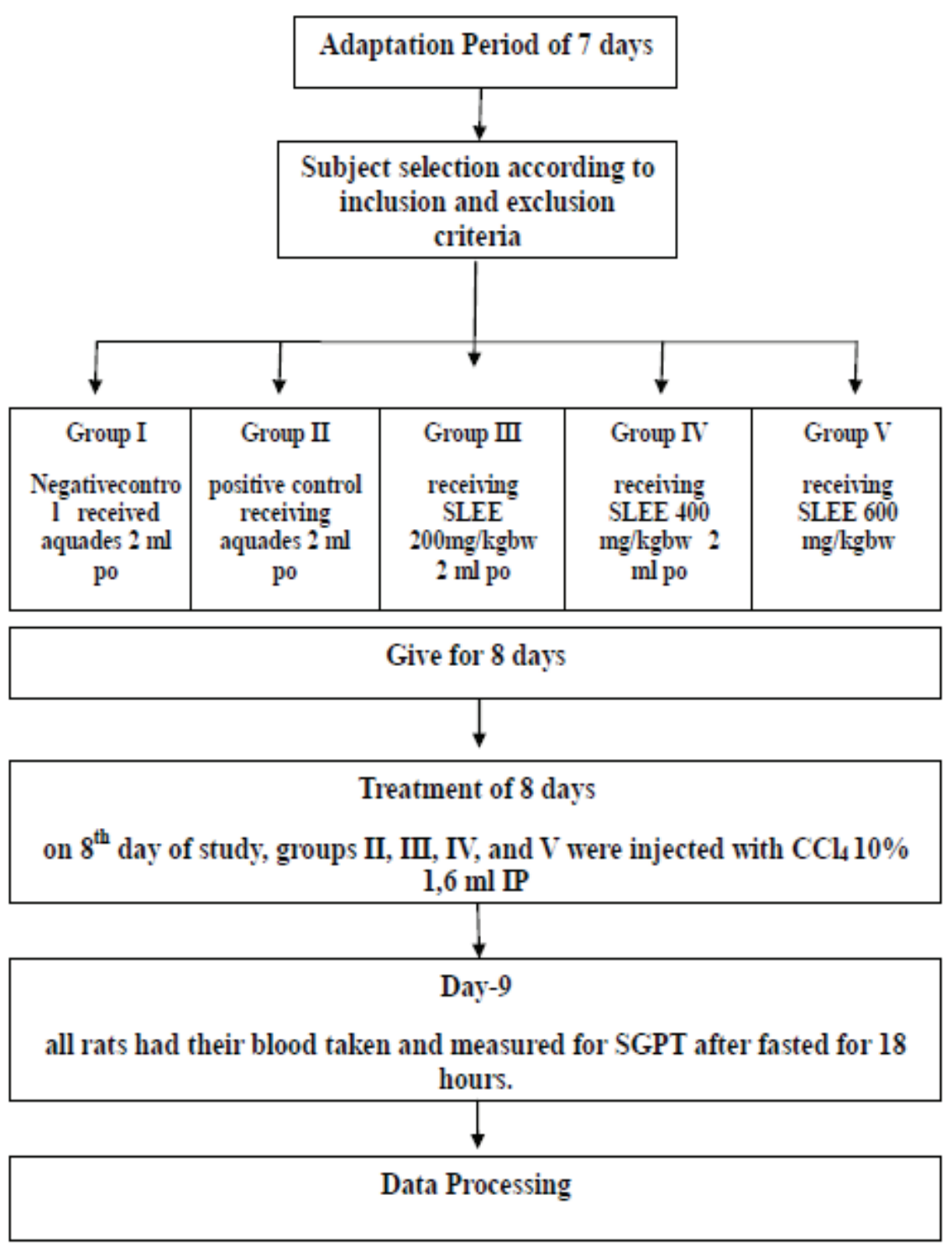

Figure 1 Procedure

II. There was a significant difference $(\mathrm{p}<0.05)$ between treatment groups, in which the $F$ value was 492.419 and had $\mathrm{p}<0.05$ (Table 1 ).

The SGPT level was recorded to continuously rise in group II. This is due to these rats that were not treated with SLEE as positive control. Group III had the most significant result on inhibiting the rise of SGPT on $\mathrm{CCl}_{4}$ induced rats with an inhibiting value of $10.609 \times 103 \mathrm{IU} / \mathrm{L}$ or $58.34 \%$.

\section{Discussion}

According to a study from Ghana ${ }^{16}$ stated that the study conducted with rats treated with soursop leaf extract with dose of $50 \mathrm{mg} /$ kgbw, $100 \mathrm{mg} / \mathrm{kgbw}, 200 \mathrm{mg} / \mathrm{kgbw}$, and 400 $\mathrm{mg} / \mathrm{kgbw}$, showed that the smallest dose of $50 \mathrm{mg} / \mathrm{kgbw}$ have the highest effectiveness. Meanwhile, the study that was conducted by the researcher in the smallest dose of $200 \mathrm{mg} / \mathrm{kgbw}$ has the highest effectiveness.

Soursop leaf extract contains acetogenins which functions as free radical scavenger (anti-oxidant) and are effective as anti-tumor agents. Anti-oxidant is substance that works to protect the cells from the effect of free radicals. However, Annona muricataLinn also contains ascorbic acid which have anti-oxidant 
effect in the body. ${ }^{3,8}$

This study concluded that Soursop Leaf Ethanol Extract have inhibiting effect of elevating the Serum Glutamat Piruvat Transminase level in rats.

\section{References}

1. Moore KL, Dalley AF. Clinically oriented anatomy. 5th ed. Philadelphia:Lippincott Williams \& Wilkins; 2006. p. 311,318.

2. Murray RK, Granner DK, Mayes PA, Rodwell VW. Harper's Illustrated Biochemistry. 28th ed. New York: McGraw-Hill; 2009.

3. Ghany M, Hoofnagle JH. Approach to the patient with liver disease. In: Kasper D, Braunwald E, Fauci AS, Hauser SL, Longo DL, Jamesoon JL, editors. Harrison's principles of internal medicine. 16th ed. New York: McGraw-Hill; 2004. p. 1808-13.

4. Kumar V, Abbas AK, Fausto N. Robbins and Cotran pathologic basis of disease. 7 th ed. Philadelphia: Elsevier Saunders; 2005.

5. Taufiq T. Ampuhnya terapi herbal berantas berbagai penyakit berat. Jogjakarta: Najah; 2011.

6. De Sousa OV, Vieira GD-V, de Jesus RG de Pinho J, Yamamoto $\mathrm{CH}$, Alves MS. Antinociceptive and anti-inflammatory activities of the ethanol extract of Annona muricata L. Leaves in animal models. Int J Mol Sci. 2010;11(5):2067-78.

7. Baskar R, Rajeswari V, Kumar TS. In vitro antioxidant studies in leaves of Annona species. Indian J ExpBiol. 2007;45(5):4805

8. Cone M. Low doses, big effects: Scientists seek 'fundamental changes' in testing, regulation of hormone-like chemicals. Environmental Health Services; 2012 [Cited 2012 November 10]; Available from: http://www.environmentalhealthnews. org/ehs/news / 2012/low-dose-big- effects.

9. Fang XP, Rieser MJ,Gu ZM, Zhao GX, McLaughlin JL. Annonaceous acetogenins: an updated review. PhytochemAnal. 1993;4(1):27-48.

10. The Society of Toxicology. Animals in research: the importance of animals in the science of toxicology. Reston:The Society of Toxicology; 2006 [Cited 2012 November 10]; Available from: http:// www.toxicology.org/ai/air/AIR_Final.pdf.

11. World Health Organization. Carbon tetrachloride: health and safety guide. Geneva: WHO; 1998.

12. Adewole S, Caxton-Martins E. Morphological changes and hypoglycemic effects of Annona muricata Linn. (Annonaceae) leaf aqueous extract on pancreatic $\beta$-cells of Streptozotocintreated diabetic rats. Afr JBiomed Res. 2006;9:173-87

13. Wu Y, Wang F, Zheng Q, Lu L, Yao H, Zhou $\mathrm{C}$, et al. Hepatoprotective effect of total flavonoids from Laggera alata against carbon tetrachloride-induced injury in primary cultured neonatal rat hepatocytes and in rats with hepatic damage. J Biomed Sci. 2006;13(4):569-78.

14. Buchanan-Smith H, Rennie AE, Vitale A, Pollo S, Prescott MJ, Morton DB. Harmonising the definition of refinement. Animal Welfare. 2005;14:379-84.

15. Kamel HH, Azza HA, Walaa MSA, Amira HM. Protective effect of some antioxidants against CCl4-induced toxicity in liver cells from BRL3A cell line. Journal of American Science. 2010;6(10):992-1003.

16. Arthur FK, Woode E, Terlabi EO, Larbie C. Evaluation of hepatoprotective effect of aqueous extract of Annona muricata (Linn.) leaf against carbon tetrachloride and acetaminophen-induced liver damage. J Nat Pharm. 2012;3(1):25-30. 